\title{
Liver Lipid Accumulation and Fatty Acid Flux in Rats Fed a Low Protein Diet Containing Purified Whole Egg Protein ${ }^{\dagger}$
}

\author{
Kazumi YAGASAKI* and Masao KAMETAKA \\ Department of Agricultural Chemistry, Faculty of Agriculture, \\ The University of Tokyo, Bunkyo-ku, Tokyo, Japan \\ Received June 29, 1976
}

\begin{abstract}
A time-course experiment related to the incorporation of palmitic acid-1 $1{ }^{14} \mathrm{C}$ was performed in growing rats fed a 5 or 20 protein calories percent $(\mathrm{PC} \%$ ) diet containing purified whole egg protein.

No difference was observed with time in the conversion of palmitic acid-1 $1{ }^{14} \mathrm{C}$ to respiratory $\mathrm{CO}_{2}$. Radioactivity present in liver triglycerides (TG) was higher and disappeared more slowly with time in the $5 \mathrm{PC} \%$ group than in the $20 \mathrm{PC} \%$ group. Conversely, significantly lower radioactivity appeared in serum TG of the $5 \mathrm{PC} \%$ group than in that of the $20 \mathrm{PC} \%$ group. A marked decrease of serum TG level was observed in the 5 PC\% group, which was attributable to a reduced concentration of TG in serum very low density lipoprotein.

From the results obtained, a decreased transport of TG from the liver to blood was considered to be a factor responsible for the liver lipid accumulation in rats fed the low protein diet.
\end{abstract}

It is well known that lipids accoumulate in the liver of animals under various nutritional conditions $^{1 \sim 5)}$ or by administration of chemical agents. ${ }^{\text {( } ~ 8)}$ Tanaka et al..$^{9)}$ reported previously that young rats fed a low protein diet containing purified whole egg protein showed specific accumulations of lipids in their livers when the diet contained the protein at $5 \mathrm{PC} \%$. $\mathrm{We}^{(0)}$ observed thereafter that the liver TG content for this low protein ( $5 \mathrm{PC} \%$ ) diet was twice as much as that for a control $(20 \mathrm{PC} \%)$ diet, whereas the concentrations of TG and apoprotein in serum VLDL for the low protein diet were significantly lower than those for the control diet when sucrose and $10 \%$ soybean oil were used as dietary carbohydrate and fat sources respectively. From these results, an

Abbreviations: $\quad \mathrm{PC} \%=$ protein calories percent, $\mathrm{TL}=$ total lipids, $\mathrm{TG}=$ triglycerides, $\mathrm{PL}=$ phospholipids, $F A=$ fatty acids, $F F A=$ free fatty acids, $V L D L=$ very low density lipoprotein, $L D L=$ low density lipoprotein, $\mathrm{LPL}=$ lipoprotein lipase.

+ Mechanism of Liver Lipid Accumulation in Low Protein Diet Feeding. Part II. See reference 10). This work was presented at the Annual Meeting of the Agricultural Chemical Society of Japan at Sapporo, Japan, on July 23, 1975.

* Present address: Kyorin Chemical Laboratory, 1-3-32 Ukima, Kita-ku, Tokyo 115. impaired transport of TG from the liver was suggested to be one of factors responsible for the lipid accumulation. Therefore, we undertook observations on the fatty acid flux in vivo through the liver with palmitic acid-1- ${ }^{14} \mathrm{C}$.

\section{MATERIALS AND METHODS}

Experimental animals and diets. Male rats of Wistar strain weighing 40 to $60 \mathrm{~g}$ were used. They were housed in individual cages with wire bottoms in a room at a temperature of $22 \pm 2^{\circ} \mathrm{C}$, a relative humidity of $60 \pm 5 \%$, and a 6 a.m. to 6 p.m. light cycle. The rats were fed a commercial stock diet (Type NMF, Oriental Yeast Co., Ltd., Tokyo) until they had reached an average weight of about $75 \mathrm{~g}$. They were divided into two groups of 11 rats each and fed the experimental diets shown in Table $I$ for 23 days. Control rats were fed a $20 \mathrm{PC} \%$ diet. For producing rats with fatty livers, a $5 \mathrm{PC} \%$ diet was used. Experimental diets and water were given ad libitum, but the rats were fasted for about 12 hr before they were sacrificed.

Injection of labeled palmitic acid. Palmitic acid-1${ }^{14} \mathrm{C} \quad(57.9 \mathrm{mCi} / \mathrm{mmole}$, the Radiochemical Centre, Amersham, England) was homogenized in 5\% human serum albumin (Fr. V Powder, Fatty Acid Free, Miles Laboratories Inc., Kankakee, USA) in $0.9 \% \mathrm{NaCl}^{11}$ and injected into the femoral vein of each rat under light ether anesthesia at a dose of $4.109 \mu \mathrm{Ci} / 0.4 \mathrm{ml} / \mathrm{rat}$ for the $20 \mathrm{PC} \%$ group or $2.055 \mu \mathrm{Ci} / 0.2 \mathrm{ml} / \mathrm{rat}$ for the $5 \mathrm{PC} \%$ group. 
Collection and determination of ${ }^{14} \mathrm{C}$ in the respiratory $\mathrm{CO}_{2}$. Immediately after injection, each rat was kept in a glass metabolism apparatus ${ }^{12)}$ for 15,45 and $105 \mathrm{~min}$ to determine the radioactivity in the expired $\mathrm{CO}_{2}$. Respiratory $\mathrm{CO}_{2}$ was trapped in a solution of methylcellosolve-monoethanolamine (2:1) mixture for 15,45 and $105 \mathrm{~min}$. Radioactivity was determined by the method of Jeffay and Alvarez ${ }^{13)}$ in an Aloka LSC 651 liquid scintillation spectrophotometer and the correction for quenching was made by the external standard method.

Preparation of serum and tissues. During the next 15 min each rat was taken out of the glass metabolism apparatus, anesthetized by an intraperitoneal injection of nembutal ( $4 \mathrm{mg} / 100 \mathrm{~g}$ body weight), and had a cannula fixed into the carotid. At the scheduled times, i.e., 30, 60 and $120 \mathrm{~min}$ after the injection of palmitic acid-1 $-{ }^{14} \mathrm{C}$, blood was collected from the cannula. An abdominal incision was made and the liver and epididymal adipose tissue were quickly removed, weighed and placed on ice. Serum was separated by centrifugation from the blood samples left to clot at room temperature for $3 \mathrm{hr}$. Total serum volume was tentatively calculated in accordance with Shiraki's equation. ${ }^{14}$ )

Isolation of serum lipoproteins. Equal amounts of serum from two or three rats of each group were pooled in order to have sufficient materials. Lipoproteins were isolated from each pooled serum by a slight modification of the method described by Lombardi and Ugazio. ${ }^{15}$ ) The saline solutions containing $\mathrm{NaCl}, \mathrm{NaBr}$ and disodium EDTA were prepared and their density was adjusted by pycnometry to $1.0307,1.019$ and 1.371 , respectively. All centrifugations were performed at $16^{\circ} \mathrm{C}$ in a Hitachi $65 \mathrm{P}$ preparative ultracentrifuge using a RP 65 rotor. To each pooled serum $(2$ to $4 \mathrm{ml})$ in a polycarbonate (Hitachi $10 \mathrm{PC}$ ) tube, saline solution

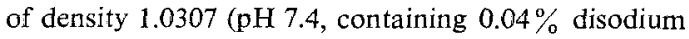
EDTA) was added in equal volumes to each pooled serum, and a final volume of $8 \mathrm{ml}$ was attained by adding saline solution of density $1.019(\mathrm{pH} 7.4$, containing $0.02 \%$ disodium EDTA). The tubes were capped and centrifuged at $105,000 \times g$ for $18 \mathrm{hr}$. After centrifugation, the floating lipoprotein of $d<1.019$ (VLDL) that accumulated in the top $1 \mathrm{ml}$ of the tube was removed with the aid of a capillary pipette. To the $7 \mathrm{ml}$ of infranatant solution, $1 \mathrm{ml}$ of saline solution of density 1.371 ( $\mathrm{pH} 7.4$, containing $0.02 \%$ disodium EDTA) was added. The tubes were capped and centrifuged at $105,000 \times g$ for $24 \mathrm{hr}$. After centrifugation, the top $2 \mathrm{ml}$, containing the lipoprotein of $1.019<d<$ 1.063 (LDL), was removed. Both lipoprotein fractions

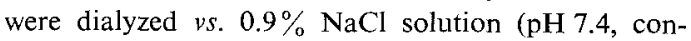
taining $0.02 \%$ disodium EDTA) for $24 \mathrm{hr}$ at $4^{\circ} \mathrm{C}$.

Lipid analysis and measurement of radioactivity. Serum, serum lipoproteins and tissue TL were ex- tracted and purified according to the method of Folch et al..$^{16)}$ A pair of epididymal adipose tissues and a representative sample of the liver which was minced and mixed with scissors were homogenized in a mixture of chloroform-methanol (2: 1) using a Polytron homogenizer (Kinematica. G.m.b.H., Lucern, Switzerland). The phase containing purified TL was evaporated to dryness. The lipid was redissolved in diethyl ether and suitable portions were applied to thin-layer chromatography on Silica Gel G (Type 60, Merck, Darmstadt, W. Germany) using a solvent system ${ }^{17}$ of petroleum ether-diethyl ether-acetic acid (80:20:1). Other suitable portions of the ether extract were transferred into vials as required, and radioactivity present in TL was determined (see below). Compounds were identified with iodine vapor. After the iodine had sublimed, the TG and PL fractions were scraped from the plates and quantitatively transferred into glass test tubes. TG were eluted from the silica gel with diethyl ether, and PL with a solvent mixture of chloroform-methanolwater-formic acid (97:97:4:2) as described by Abramson and Bleicher. ${ }^{18}$ ) The eluates were filtered through Toyo No. $5 \mathrm{C}$ paper and portions of the filtrates were transferred to vials. After evaporation of the solvents in a desiccator at reduced pressure, $15 \mathrm{ml}$ of a toluene scintillator ${ }^{10}$ was added. Radioactivity was determined as described above. With regard to serum and serum lipoproteins, TG were also determined by the calorimetric method of Van Handel, ${ }^{19}$ )

\section{RESULTS}

As shown in Table II, the final body weight of the $5 \mathrm{PC} \%$ group was half that of the $20 \mathrm{PC} \%$ group. When the liver weight was expressed in values relative to $100 \mathrm{~g}$ body weight, the value of the $5 \mathrm{PC} \%$ group was slightly, but significantly, higher than that of the $20 \mathrm{PC} \%$ group, i.e., the livers of the $5 \mathrm{PC} \%$ group were relatively enlarged in comparison with those of the $20 \mathrm{PC} \%$ group. In adipose tissue, however, there was no significant difference between relative values for the 20 and $5 \mathrm{PC} \%$ groups.

Table III shows the concentrations of TG in whole serum and serum lipoproteins. There was a marked decrease in the level of serum TG in the $5 \mathrm{PC} \%$ group which was due to a reduced concentration of this lipid in VLDL.

The respiratory $\mathrm{CO}_{2}$ was collected for 15 , 45 and $105 \mathrm{~min}$ after the injection of palmitic acid- $1-{ }^{14} \mathrm{C}$ (Fig. 1). At no time was a significant difference observed in the conversion of 
Table I. Composition of Experimental Diets

\begin{tabular}{|c|c|c|}
\hline Diet (group) & $\begin{array}{c}5 \mathrm{PC} \% \\
\text { (low protein) }\end{array}$ & $\begin{array}{l}20 \mathrm{PC} \% \\
\text { (control) }\end{array}$ \\
\hline & \multicolumn{2}{|c|}{$\mathrm{g} / 100 \mathrm{~g}$ of diet } \\
\hline Sucrose & 74.9 & 59.5 \\
\hline Whole egg protein ${ }^{a}$ ) & 5.13 & 20.5 \\
\hline Soybean oil & 10.0 & 10.0 \\
\hline Cellulose powder $\left.{ }^{b}\right)$ & 5.00 & 5.00 \\
\hline Salt mixture ${ }^{c}$ ) & 4.00 & 4.00 \\
\hline Vitamin mixture $^{d s}$ & 0.85 & 0.85 \\
\hline Choline chloride & 0.15 & 0.15 \\
\hline \multicolumn{3}{|l|}{ Metabolizable } \\
\hline energy $^{e)}(\mathrm{kcal})$ & 410 & 410 \\
\hline Protein calories $\%$ f & 5 & 20 \\
\hline
\end{tabular}

a) Taiyo Foods Co., Ltd., Yokkaichi, Japan. ${ }^{8)}$

b) Toyo Roshi Co., Ltd., Tokyo, Japan.

c) Tanabe Amino Acid Research Foundation, Osaka, Japan.

d) See. ${ }^{\text {s }}$ Additionally supplemented with $300 \mathrm{IU}$ retinyl palmitate, $100 \mathrm{IU}$ ergocalciferol and $5 \mathrm{mg}$ $d l$ - $\alpha$-tocopherol per $100 \mathrm{~g}$ of diet.

e) Sucrose (g) $\times 4+$ whole egg protein (g) $\times 4+$ soybean oil $(\mathrm{g}) \times 9(\mathrm{kcal} / 100 \mathrm{~g}$ of diet $)$.

f) Whole egg protein- $\mathrm{N} \times 6.25 \times 4 \times 100 /$ metabolizable energy.

palmitic acid- $1-{ }^{14} \mathrm{C}$ to expired $\mathrm{CO}_{2}$.

Figure 2 shows the incorporation of palmitic acid- $1{ }^{14} \mathrm{C}$ into liver TL, liver and serum PL. Radioactivity present in liver TL was almost the same during the first $60 \mathrm{~min}$ but that of the $5 \mathrm{PC} \%$ group was significantly higher than that of the $20 \mathrm{PC} \%$ group at the $120 \mathrm{~min}$ point, which was essentially due to a considerable loss of radioactivity from liver TL of the $20 \mathrm{PC} \%$ group but only a small loss from liver $\mathrm{TL}$ of the $5 \mathrm{PC} \%$ group. No significant difference, however, was observed in the incorporation of palmitic acid- $1-{ }^{14} \mathrm{C}$ into liver PL as time went on. These findings indicate that a small loss of radioactivity from,

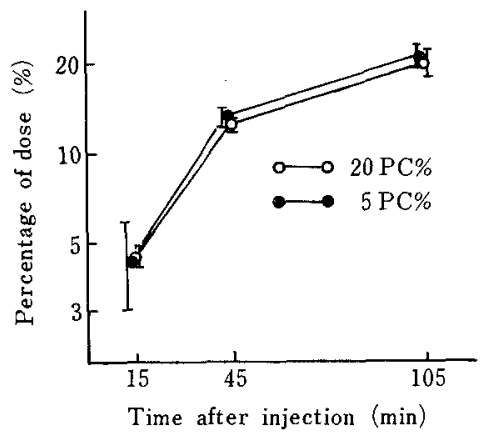

FIg. 1. Conversion of Palmitic Acid-1 $-{ }^{14} \mathrm{C}$ to Respiratory Carbon Dioxide $\left(\mathrm{CO}_{2}\right)$.

Each point represents the mean \pm SEM of three (15 $\mathrm{min}$ ) or four $(45,105 \mathrm{~min})$ rats.

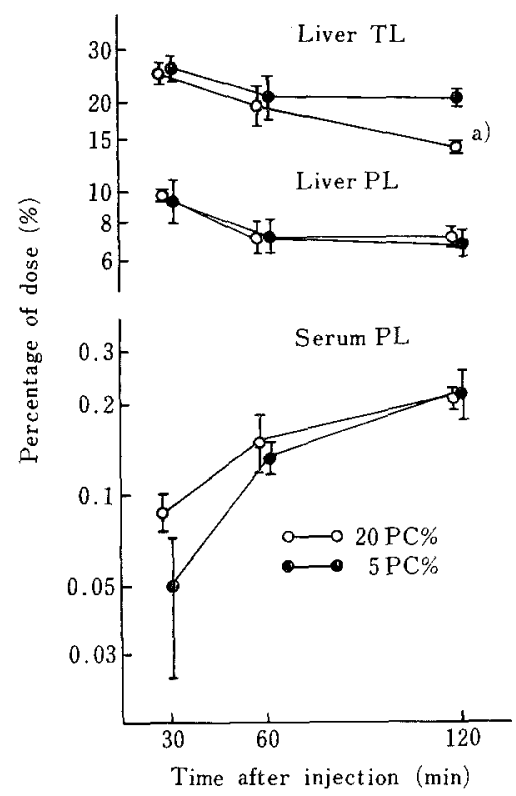

Frg. 2. Incorporation of Palmitic Acid $-1-^{14} \mathrm{C}$ into Liver Total Lipids (TL), Liver and Serum Phospholipids (PL).

Each point represents the mean \pm SEM of three (30 min) or four $(60,120 \mathrm{~min})$ rats.

a) $P<0.01$ to $5 \mathrm{PC} \%$ group.

Table II. Data on Rats Used for Palmitic Acid- $1-{ }^{14} \mathrm{C}$ INCORPORATION EXPERIMENT in vivo

Each value represents the mean \pm SEM of eleven rats.

\begin{tabular}{|c|c|c|c|c|}
\hline $\begin{array}{l}\text { Diet } \\
\text { (group) } \\
\text { PC } \%\end{array}$ & $\begin{array}{c}\text { Final body } \\
\text { weight } \\
\mathrm{g}\end{array}$ & $\begin{array}{l}\text { Body weight } \\
\text { gain } \\
\text { g/day }\end{array}$ & $\begin{array}{c}\text { Liver } \\
\text { weight } \\
\mathrm{g} / 100 \mathrm{~g} \mathrm{bwt}\end{array}$ & $\begin{array}{c}\text { Epididymal adipose } \\
\text { tissue weight } \\
\mathrm{g} / 100 \mathrm{~g} \mathrm{bwt}\end{array}$ \\
\hline 20 & $228.0 \pm 7.5^{a)}$ & $6.6 \pm 0.3^{a)}$ & $\left.4.24 \pm 0.17^{a}\right)$ & $1.30 \pm 0.09$ \\
\hline 5 & $114.6 \pm 5.1$ & $1.6 \pm 0.2$ & $5.55 \pm 0.28$ & $1.17 \pm 0.07$ \\
\hline
\end{tabular}

\footnotetext{
a) $P<0.005$ to $5 \mathrm{PC} \%$ group.
} 
Table III. Concentration of Whole Serumand Serum Lipoprotein-TG in Rats Fed 20 OR 5 PC \% DIET

Each value represents the mean $\perp S E M$ of eleven (whole serum) or five (VLDL, LDL) samples.

\begin{tabular}{|c|c|c|c|}
\hline \multirow{2}{*}{$\begin{array}{c}\text { Diet } \\
\text { (group) } \\
\text { PC } \%\end{array}$} & \multicolumn{3}{|c|}{ Triglycerides } \\
\hline & Whole serum & $\begin{array}{l}\text { VLDL } \\
/ 100 \mathrm{ml} \text { of ser }\end{array}$ & LDL \\
\hline 20 & $\left.29.9 \pm 4.1^{a}\right)$ & $26.4 \pm 3.5^{a)}$ & $2.3 \pm 0.2$ \\
\hline 5 & $10.8 \pm 0.6$ & $7.3 \pm 1.2$ & $2.8 \pm 0.4$ \\
\hline
\end{tabular}

or a stagnation of radioactivity in, liver TL of the $5 \mathrm{PC} \%$ group is not due to the stagnation of radioactivity in liver PL but to stagnation in other lipid classes of the liver. Radioactivity present in serum PL rose gradually in both groups with time, and during the first $60 \mathrm{~min}$ it was somewhat, but not significantly, lower in the $5 \mathrm{PC} \%$ group than in the $20 \mathrm{PC} \%$ group.

The time curves for radioactivity present in the liver and serum TG, and epididymal adipose tissue TL are shown in Fig. 3. Radioactivity in liver TG was higher at all points, especially significantly higher at the $120 \mathrm{~min}$ point, in the $5 \mathrm{PC} \%$ group than in the $20 \mathrm{PC} \%$ group. As the time proceeded, radioactivity present in liver TG declined in both groups but declined more slowly in the $5 \mathrm{PC} \%$ group than in the $20 \mathrm{PC} \%$ group. No significant difference was observed in the incorporation of plamitic acid-1-1 ${ }^{14} \mathrm{C}$ into liver PL (Fig. 2). TG, as well as PL, are the major lipid calss in liver lipids. Therefore, it can be considered that the stagnation of radioactivity in liver $\mathrm{TG}$ of the $5 \mathrm{PC} \%$ group was reflected in the trend of radioactivity in liver $\mathrm{TL}$ of the $5 \mathrm{PC} \%$ group. Radioactivity present in serum TG was lower in the $5 \mathrm{PC} \%$ group than in the $20 \mathrm{PC} \%$ group at all times. Specific radioactivity was also significantly lower during the first $60 \mathrm{~min}$ and tended to be lower after $120 \mathrm{~min}$ in the $5 \mathrm{PC} \%$ group than in the $20 \mathrm{PC} \%$ group (Table IV). In adipose tissue $\mathrm{TL}$, in which $\mathrm{TG}$ are the major lipid class, no significant difference and no systematic change were observed between the two 20 and $5 \mathrm{PC} \%$

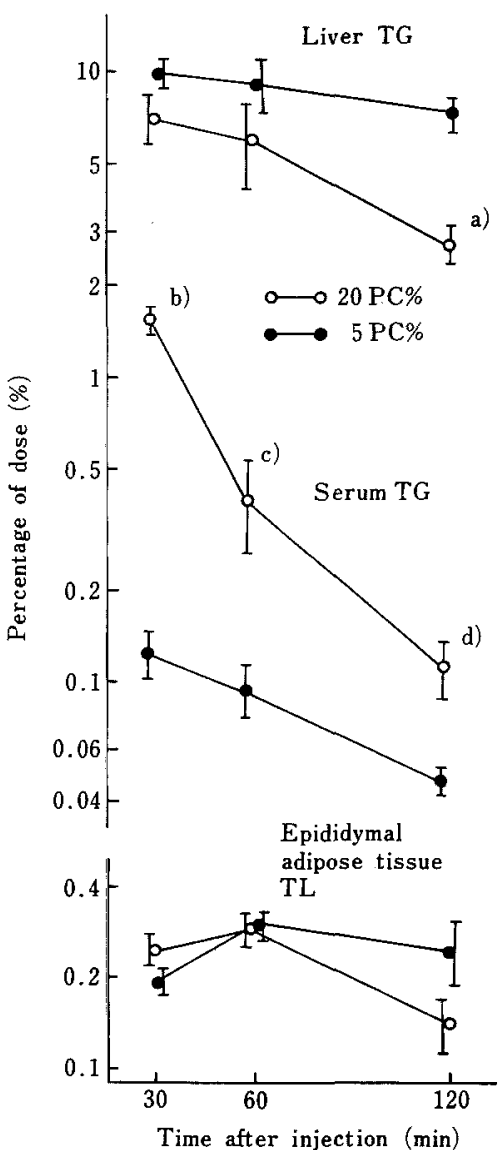

FIG. 3. Incorporation of Palmitic Acid-1 $-{ }^{14} \mathrm{C}$ into Liver and Serum Triglycerides (TG), and Epididymal Adipose Tissue Total Lipids (TL).

Each point represents the mean $\pm S E M$ of three (30 min) of four $(60,120 \mathrm{~min})$ rats.
a) $P<0.01$ to $5 \mathrm{PC} \%$ group.
b) $P<0.005$ to $5 \mathrm{PC} \%$ group.
c) $P<0.1$ to $5 \mathrm{PC} \%$ group.
d) $P<0.02$ to $5 \mathrm{PC} \%$ group.

Table IV. Specific Radioactivity of Serum TG after INJeCtion of Palmitic ACID $-1{ }^{-14} \mathrm{C}$ into RATS FED 20 OR 5 PC\% DIET

Each value represents the mean $\pm S E M$ of three (30 $\mathrm{min})$ or four $(60,120 \mathrm{~min})$ samples.

\begin{tabular}{lccc}
\hline $\begin{array}{c}\text { Diet } \\
\text { (group) } \\
\text { PC } \%\end{array}$ & \multicolumn{3}{c}{ Time after injection (min) } \\
\hline 20 & $44.7 \pm 4.2^{a)}$ & $\begin{array}{c}60 \\
\text { dpm } / \mu \mathrm{g} \text { of TG }\end{array}$ \\
\hline 5 & $8.1 \pm 2.9$ & $6.4 \pm 1.6$ & 120 \\
\hline a) & $P<0.005$ to $5 \mathrm{PC} \%$ group. & $3.22 \pm 0.39$ \\
b) & $P<0.05$ to $5 \mathrm{PC} \%$ group. \\
c) & $P<0.1$ to $5 \mathrm{PC} \%$ group.
\end{tabular}


Table V. Percentage of Radioactivity between SERUM AND LIVER TG AFTER INJECTION OF PALMITIC ACID $-1-14$ C InTo RATs Fed 20 or 5 PC\% Diet

Each value represents the mean of three $(30 \mathrm{~min}$ ) or four $(60,120 \mathrm{~min})$ samples.

\begin{tabular}{ccccr}
\hline $\begin{array}{c}\text { Time } \\
\text { after } \\
\text { injection } \\
\text { min }\end{array}$ & $\begin{array}{c}\text { Diet } \\
\text { (group) } \\
\text { PC } \%\end{array}$ & $\begin{array}{c}\text { Liver } \\
\text { TG } \\
\%\end{array}$ & $\begin{array}{c}\text { Serum of } \\
\text { TG }\end{array}$ & $\begin{array}{c}\text { Percentage } \\
\text { of serum TG } \\
\text { to liver TG } \\
\%\end{array}$ \\
\hline 30 & 20 & 7.09 & 1.541 & 22.54 \\
& 5 & 9.80 & 0.125 & 1.33 \\
60 & 20 & 5.93 & 0.399 & 10.30 \\
& 5 & 9.06 & 0.094 & 1.57 \\
120 & 20 & 2.70 & 0.111 & 4.41 \\
& 5 & 7.12 & 0.047 & 0.69 \\
\hline
\end{tabular}

groups (Fig. 3).

As shown in Table $\mathrm{V}$, the percentage of radioactivity between serum and liver $T G$ was markedly lowered in the $5 \mathrm{PC} \%$ group compared with the $20 \mathrm{PC} \%$ group at all times. The values for the $5 \mathrm{PC} \%$ group were unchanged except for the 120 min value, whereas those of the $20 \mathrm{PC} \%$ group dropped rapidly with time.

\section{DISCUSSION}

It was found previously ${ }^{10}$ that the concentration of FFA in $d>1.063$ lipoproteins, which contain albumin-FFA complexes, was unchanged between the two 20 and $5 \mathrm{PC} \%$ groups. This result rules out the possibility that the accumulation of liver $\mathrm{TG}$ in the $5 \mathrm{PC} \%$ group is due to increased mobilization of FFA from adipose tissue to the liver.

It appears that the FA oxidation ability is not impaired in the $5 \mathrm{PC} \%$ group at the whole animal level (Fig. 1). As pointed out by Yoshida and Harper, ${ }^{1)}$ the FA oxidation ability in the liver alone cannot be confirmed from the data in experiments on intact animals. In the experiment with the perfused liver, however, no evidence was obtained that the FA oxidation ability is impaired in the $5 \mathrm{PC} \%$ group. $^{20)}$ Consequently, it is also unlikely that the accumulation of liver TG in the $5 \mathrm{PC} \%$ group results from the impaired FA oxidation ability in the liver.

Decreased transport of TG from the liver to blood is usually reflected by a lower level of serum TG. ${ }^{15,21)}$ In the fasting state, the liver is the major source of serum TG. ${ }^{22}$ In rats fasted for $12 \mathrm{hr}$, a marked decrease of serum TG level was observed in the $5 \mathrm{PC} \%$ group, which was attributed to a reduced concentration of TG in VLDL (Table III), confirming previous observations. ${ }^{101}$ It was also reported previously that the concentration of apoprotein in VLDL was lower in the $5 \mathrm{PC} \%$ group than the $20 \mathrm{PC} \%$ group. $^{10)}$ These results, therefore, suggest that the transport of $\mathrm{TG}$ from the liver to blood is impaired in the $5 \mathrm{PC} \%$ group.

The release of liver TG into the blood has been assessed by a time study of the incorporation of labeled FA into liver and serum (or plasma) TG. ${ }^{21,23)}$ As shown in Fig. 3, after the injection of palmitic acid $-1-{ }^{14} \mathrm{C}$, radioactivity present in liver TG was higher and disappeared more slowly with time in the $5 \mathrm{PC} \%$ group than in the $20 \mathrm{PC} \%$ group. Conversely, lower radioactivity appeared in serum TG of the $5 \mathrm{PC} \%$ group than in that of the $20 \mathrm{PC} \%$ group. Specific radioactivity of serum TG was also lower at all times in the $5 \mathrm{PC} \%$ group than in the $20 \mathrm{PC} \%$ group (Table IV). These findings (also see Table V) strongly indicate the impaired transport of liver TG into blood in the $5 \mathrm{PC} \%$ group.

In the fasting state, ${ }^{23)}$ the serum $\mathrm{TG}$ level depends mainly on the balance between the release of TG from the liver and the removal of TG-FA in the extrahepatic tissues by the action of LPL. Under these conditions, the activity of LPL in adipose tissue is low and serum TG-FA are directed predominantly towards the muscular tissues and oxidation. ${ }^{24}$ ) No difference was observed in the conversion of palmitic acid-1-14 $\mathrm{C}$ to respiratory $\mathrm{CO}_{2}$ between the two 20 and $5 \mathrm{PC} \%$ groups at the whole animal level (Fig. 1), and in the perfused liver the ability of this conversion to $\mathrm{CO}_{2}$ was found not to be impaired in the $5 \mathrm{PC} \%$ group compared with the $20 \mathrm{PC} \%$ group, ${ }^{20}$ ) excluding the possibility that the extrahepatic tissues (mainly muscular tissues) take up and oxidize more serum TG-FA of the $5 \mathrm{PC} \%$ 
group than of the $20 \mathrm{PC} \%$ group. In addition, the incorporation of palmitic acid- $1-{ }^{14} \mathrm{C}$ into adipose tissue TL did not rise significantly in the $5 \mathrm{PC} \%$ group (Fig. 3), although the contribution of this tissue towards the removal of TG-FA is minor in the fasting state. $^{24)}$ It appears, therefore, unlikely that the reduction of serum TG level and of incorporation of palmitic acid- $1{ }^{14} \mathrm{C}$ into serum $\mathrm{TG}$ in the $5 \mathrm{PC} \%$ group was due to faster utilization of serum TG-FA by the extrahepatic tissues.

Lecithins are the major PL class in the liver, ${ }^{25)}$ as well as in serum. ${ }^{26)}$ In choline deficient rats, ${ }^{1,21}$ the incorporation of labeled palmitic acid into liver PL was found to be lower than that in control rats but in the present study, no difference was observed between the two 20 and $5 \mathrm{PC} \%$ groups, reflecting an adequate supplement of choline in the experimental diets. Measurement of the incorporation of palmitic acid- $1-{ }^{14} \mathrm{C}$ into serum PL provides indirect information on the release of liver TG, since serum PL, as well as TG in the fasting state, are released by the liver. No clear-cut evidence, however, was obtained from the incorporation of palmitic acid- $1{ }^{14} \mathrm{C}$ into serum PL (Fig. 2) such as that into serum TG (Fig. 3). As described by Lombardi et al., ${ }^{21)}$ the major reasons for such a low sensitivity in serum PL are (a) the considerably slower turnover of serum PL, and (b) the fact that among serum lipoproteins, the VLDL fraction has the fastest turnover but the lowest content of PL.

Acknowledgement. The authors wish to express their gratitude to Dr. M. Yamaguchi, the National Institute of Nutrition, and Dr. H. Tanaka, Utsunomiya University, for their helpful advice and instruction.

\section{REFERENCES}

1) A. Yoshida and A. E. Harper, J. Biol. Chem., 235, 2586 (1960).

2) A. Seakins and D. S. Robinson, Biochem. J.,
92, 308, (1964).

3) B. Lombardi and A. Oler, Lab. Invest., 17, 308 (1967).

4) A. J. Sinclair and F. D. Collins, Biochim. Biophys. Acta, 152, 498 (1968).

5) V. N. Singh, M. Singh and T. A. Venkitasubramanian, J. Lipid Res., 10, 395 (1969).

6) D. S. Robinson and A. Seakins, Biochim. Biophys. Acta, 62, 163 (1962).

7) B. Lombardi, Fed. Proc., 24, 1200 (1965).

8) P. S. Roheim, S. Switzer, A. Girard and H. A. Eder, Lab. Invest., 15, 21 (1966).

9) H. Tanaka, M. Yamaguchi and M. Kametaka, Agric. Biol. Chem., 38, 1113 (1974).

10) K. Yagasaki, H. Tanaka, M. Yamaguchi and M. Kametaka, Nippon Nôgeikagaku Kaishi, 49, 387 (1975).

11) R. Sheig and K. J. Isselbacher, J. Lipid Res., 6, 269 (1965).

12) H. Tanaka, M. Yamaguchi and M. Kametaka, Agric. Biol. Chem., 39, 507 (1975).

13) H. Jeffay and J. Alvarez, Anal. Chem., 33, 612 (1961).

14) K. Shiraki, J. Japan. Soc. Food Nutr., 25, 475 (1972).

15) B. Lombardi and G. Ugazio, J. Lipid Res., 6, 498 (1965).

16) J. Folch, M. Lees and G. H. Sloane Stanley, J. Biol. Chem., 226, 497 (1957).

17) M. Ogura, H. Tanaka and H. Honda, Agric. Biol. Chem., 35, 370 (1971).

18) D. Abramson and M. Bleicher, J. Lipid Res., 5, 628 (1964).

19) E. Van Handel, Clin. Chem., 7, 249 (1961).

20) K. Yagasaki and M. Kametaka, Abstracts of Papers, Annual Meeting of the Agricultural Chemical Society of Japan, Kyoto, April, 1976, p. 144 .

21) B. Lombardi, P. Pani and F. F. Schlunk, $J$. Lipid Res., 9, 437 (1968).

22) S. O. Byers and M. Friedman, Am. J. Physiol., 198, 629 (1960).

23) T. Fukazawa, O.S. Privett and Y. Takahashi, Lipids, 6, 388 (1971).

24) D. S. Robinson, "Comprehensive Biochemistry," Vol. 18, ed. by M. Florkin and E. L. Stotz, Elsevier Publishing Co., Amsterdam, 1970, p. 51.

25) K. Imaizumi, M. Sugano and M. Wada, Agric. Biol. Chem., 36, 234 (1972).

26) H. A. I. Newman, C. T. Liu and D. B. Zilversmit, J. Lipid Res., 2, 403 (1961). 